\title{
Thiothymidine combined with UVA as a potential novel therapy for bladder cancer
}

\author{
SW Pridgeon',5, R Heer ${ }^{1,4}$, GA Taylor', DR Newell', K O'Toole', M Robinson'², Y-Z Xu', P Karran ${ }^{3}$ and \\ AV Boddy,
}

'Northern Institute for Cancer Research, Medical School, Newcastle University, Newcastle NE2 4HH, UK; ${ }^{2}$ Department of Histopathology, Royal Victoria Infirmary, Newcastle, UK; ${ }^{3}$ Cancer Research UK London Research Institute, Clare Hall Laboratories, South Mimms, UK; ${ }^{4}$ Department of Urology, Freeman Hospital, Newcastle, UK

BACKGROUND: Thiothymidine $\left(S^{4} T d R\right)$ can be incorporated into DNA and sensitise cells to DNA damage and cell death following exposure to UVA light. Studies were performed to determine if the combination of $S^{4} T d R$ and UVA could be an effective treatment for bladder cancer.

METHODS: Uptake and incorporation of $S^{4} T d R$ was determined in rat and human bladder tumour cell lines. Measures of DNA crosslinking and apoptosis were also performed. In vivo activity of the combination of $S^{4} T d R$ and UVA was investigated in an orthotopic model of bladder cancer in rats.

RESULTS: Thiothymidine (200 $\mu \mathrm{M})$ replaced up to $0.63 \%$ of thymidine in rat and tumour bladder cancer cells. The combination of $S^{4} T d R(10-200 \mu \mathrm{M})$ and UVA $\left(1-5 \mathrm{~kJ} \mathrm{~m}^{-2}\right)$ caused apoptosis and cell death at doses that were not toxic alone. Addition of raltitrexed (Astra Zeneca, Alderley Edge, Cheshire, UK) increased the incorporation of $\mathrm{S}^{4} \mathrm{TdR}$ into DNA (up to 20-fold at IC 5 ) and further sensitised cells to UVA. Cytotoxic effect was associated with crosslinking of DNA, at least partially to protein. Intravenous administration of $S^{4} T d R$, in combination with UVA delivered directly to the bladder, resulted in an antitumour effect in three of five animals treated.

CONCLUSION: These data indicate that the combination of $\mathrm{S}^{4} \mathrm{TdR}$ and UVA has potential as a treatment for bladder cancer, and give some insight into the mechanism of action. Further work is necessary to optimise the delivery of the two components.

British Journal of Cancer (201I) 104, 1869-1876. doi:10.1038/bjc.201 I.180 www.bjcancer.com

Published online 24 May 2011

(c) 20II Cancer Research UK

Keywords: Thiothymidine; UVA; bladder cancer; raltitrexed; DNA damage

In the UK, transitional cell carcinoma (TCC) of the urinary bladder is the fifth most commonly diagnosed malignancy with 10091 new cases reported in 2007 (CRUK Cancer Statistics, 2010).

The prevalence of this disease significantly exceeds its primary incidence as it has a high rate of recurrence ranging from $31 \%$ at 5 years for low-risk tumours to $78 \%$ at 5 years for high-risk tumours (Babjuk et al, 2008). Bladder cancer can be broadly classified based on two distinct molecular and histological TCC pathologies - nonmuscle invasive bladder cancer (NMIBC) and muscle invasive bladder cancer (MIBC) (Knowles, 2008). Approximately $75-85 \%$ of patients present with NMIBC (Parker et al, 1996), and these cancers are associated with a relatively benign course rarely affecting survival, however, surveillance and recurrence makes this an expensive disease to manage. In NMIBC, the presence of multifocal disease, high-grade tumours or with concomitant carcinoma in situ is associated with the molecular biology of the aggressive variant of TCC (MIBC). These NMIBC patients have a high risk of both recurrence and disease

\footnotetext{
*Correspondence: Dr AV Boddy; E-mail: alan.boddy@ncl.ac.uk

${ }^{5}$ Current address: Department of Urology, Royal Free Hospital, Hampstead, London, UK

Received 4 February 2011; revised 20 April 2011; accepted 28 April 20I I; published online 24 May 20II
}

progression into MIBC. Once there is MIBC, contemporary overall survival at 5 years following cystectomy is $50-60 \%$ (Shariat et al, 2003). Intravesical Bacille Calmette-Guérin (BCG) therapy is currently the favoured treatment for high-risk patients despite significant morbidity. Treatment with BCG reduces the odds of progression by $27 \%$ in patients with intermediate- and high-risk tumours (Sylvester et al, 2002). Patients who fail to respond to BCG require radical and morbid surgery for the best possible chance of a cure, and new approaches to reduce progression are a clinical priority. As the bladder can be accessed readily via the transurethral route, it is ideal for topical photosensitive treatments, as exemplified by the increasing use of photodynamic bladder cancer diagnostics, and this potential is further explored in a preclinical model in this paper.

4-Thiothymidine ( $\left.\mathrm{S}^{4} \mathrm{TdR}\right)$ is a pyrimidine nucleoside thio analogue. Although it has close structural similarities to thymidine (TdR), the two molecules have markedly different ultraviolet absorbance spectra. Thymidine absorbs maximally at $270 \mathrm{~nm}$ (UVC) while the peak absorption of $S^{4} \mathrm{TdR}$ is in the UVA range at $340 \mathrm{~nm}$.

The altered photospectrum of $S^{4} \mathrm{TdR}$ enables it to form photochemical DNA intrastrand crosslinks (Warren et al, 1998) and DNA-protein crosslinks. These properties have been used to investigate the structural and functional interactions of DNA-binding proteins with synthetic oligonucleotides containing 
$S^{4}$ TdR (Nikiforov and Connolly, 1992). Interstrand DNA crosslinks are also formed and $\mathrm{S}^{4} \mathrm{TdR}$-containing oligonucleotides can be photoligated in aqueous solution (Liu and Taylor, 1998). Importantly, these types of photochemical DNA lesion in cellular DNA are all potentially cytotoxic.

Thiothymidine incorporation into DNA and a consequent sensitisation to UVA has been demonstrated in various cultured skin cell lines (Massey et al, 2001; Reelfs et al, 2007). The cytotoxic effect is hypothesised to result partly from the formation of bulky DNA intrastrand crosslinks. Incorporation of $\mathrm{S}^{4} \mathrm{TdR}$ is dependent on the thymidine salvage pathway mediated by thymidine kinase (TK). This raises the possibility that inhibiting de novo synthesis of thymidine nucleotides might increase DNA $\mathrm{S}^{4} \mathrm{TdR}$ incorporation by forcing increased reliance on thymidine salvage. Raltitrexed $(\mathrm{N}-$ (5[3,4-dihydro-2-methyl-4-oxoquinazolin-6-ylmethyl]-N-methylamino -2-thenoyl)-L-glutamic acid/'Tomudex'/ZD1694) is a water soluble quinazoline-based antifolate that is a specific inhibitor of thymidylate synthase (TS), a key enzyme in the de novo pathway (Jackson et al, 1983; Mitrovski et al, 1994). In bladder cancer cells, TS inhibition results in both an increased TK activity and upregulated expression of the nucleotide transporter protein to maintain thymidylate levels through pyrimidine salvage (Pressacco et al, 1995). It is hypothesised that raltitrexed might be used to increase thiothymidine uptake into cells and incorporation into DNA and subsequently to increase the sensitivity to UVA.

\section{MATERIALS AND METHODS}

\section{Cell culture}

MYU-3L (Kameyama et al, 1993; Kawamata et al, 1993), MBT2 (Soloway et al, 1973), RT4 (Rigby and Franks, 1970) and AY27 bladder cancer cell lines were cultured in RPMI-1640 medium supplemented with $10 \%$ foetal bovine serum, penicillin and streptomycin in a humidified atmosphere of $95 \%$ air, $5 \% \mathrm{CO}_{2}$ at $37^{\circ}$ C. AY -27 TCC cells were a kind gift from Ronald Moore (Professor of Surgery and Oncology, University of Alberta), and were derived from primary rat tumours established by the oral administration of FANFT.

\section{Determination of the $S^{4} \mathrm{TdR}$ content of DNA}

Thiothymidine was added to culture medium to achieve concentrations of $1-200 \mu \mathrm{M}$ for two cell-doubling times (Table 1).The DNA was extracted using Qiagen DNeasy and converted to deoxynucleosides by successive digestion with DNAse I (Sigma, Poole, UK), nuclease P1 and alkaline phosphatase (Roche $\mathrm{GmbH}$, Mannheim, Germany). Quantification of $\mathrm{S}^{4} \mathrm{TdR}$ and thymidine nucleosides was carried out using a Perkin Elmer LC System (Beaconsfield, Buckinghamshire, UK) coupled to an API-4000 LC/MS/MS Triple Quadrupole Mass Spectrometer (Applied Biosystems, Warrington, UK), with Analyst software for data

Table I $S^{4} T d R$ incorporation into DNA following RTX treatment

\begin{tabular}{lcccc}
\hline & & \multicolumn{3}{c}{ \% $\mathbf{S}^{\mathbf{4}} \mathbf{T d R}$ incorporation amount (fold increase) } \\
\cline { 3 - 5 } Cell line & time (h) & No RTX & IC $_{\mathbf{5}}$ RTX & IC $_{\mathbf{5 0}}$ RTX \\
\hline RT4 & 35 & 0.15 & $2.71(19.7)$ & $8.16(59.1)$ \\
MYU-31 & 26 & 0.22 & $1.55(7.1)$ & $2.48(11.4)$ \\
MBT2 & 21 & 0.50 & $1.96(3.9)$ & $2.60(5.2)$ \\
AY27 & 19 & 0.63 & $2.26(3.6)$ & $4.76(7.6)$ \\
\hline
\end{tabular}

Data from cells cultured in $100 \mu \mathrm{M} S^{4} T d R$ with the stated concentrations of RTX for two cell-doubling times. Fold increases in $S^{4} T d R$ incorporation are relative to culture with no RTX. ${ }^{a}$ The amount of $\mathrm{S}^{4} \mathrm{TdR}$ incorporated is expressed as the percentage of TdR replaced by $S^{4} T d R$. (IC 5 and $I C_{50}$ concentrations: RT4 $2.5 \mathrm{nM}, 5.6 \mathrm{nM} ; \mathrm{MYU}-3 \mathrm{~L}$ 3.5 nM, I 7.5 nM; MBT2 4.0 nM, 8.1 nM; AY27 0.5 nM, 4.0 nM, respectively). acquisition and analysis. Separation was performed on a Phenomenex $20 \times 4.0 \mathrm{~mm}$ Luna $3 \mathrm{u} \mathrm{C}_{18}$ Mercury column. Mobile phase consisted of $0.05 \mathrm{M} \mathrm{NH}_{3} \mathrm{Ac} \mathrm{pH} 5.0 /$ methanol at $0.2 \mathrm{ml}$ per minute. Positive ESI mode was used with $\mathrm{m} / \mathrm{z}$ 242.9/127.1 for thymidine and $\mathrm{m} / \mathrm{z} 259.1 / 143.0$ for $\mathrm{S}^{4} \mathrm{TdR}$ and the limits of detection were $2.5 \mathrm{pg}$ and $0.25 \mathrm{pg}$, respectively. The $\mathrm{S}^{4} \mathrm{TdR}$ content of DNA was expressed as the percentage of DNA thymidine replaced by $\mathrm{S}^{4} \mathrm{TdR}$.

\section{UVA exposure}

Cells cultured in dishes or plates were exposed to UVA using a Philips facial Studio HB 175 (Philips, Guildford, UK). The distance between the plates and the lamp was measured to deliver a dose rate of $5 \mathrm{~mW} \mathrm{~cm}^{-2}$ UVA. Under these conditions, a $1 \mathrm{sec}$ exposure under the lamp corresponded to $0.05 \mathrm{~kJ} \mathrm{~m}^{-2}$.

\section{Determination of growth inhibition}

Cells were cultured in the presence of $S^{4} \mathrm{TdR}$ for two cell-doubling times. Plates were then exposed to UVA as described above and were re-incubated for a further $72 \mathrm{~h}$. Cell growth was determined using the Sulforhodamine B (SRB) assay (Skehan et al, 1990) and growth inhibition expressed as a percentage of growth compared with untreated controls.

\section{Comet assay}

The Comet assay was performed using components of the CometAssayKit (Trevigen, Oxford, UK). For UVA exposure, cells were detached from the dishes and re-suspended in PBS. Cells were re-suspended at a concentration of $5 \times 10^{5}$ cells ml $^{-1}$ and mixed with molten LM Agarose (Trevigen) in a ratio of $1: 10$ and $75 \mu$ l of the suspension placed on Comet slides (Trevigen). Electrophoresis was carried out for $20 \mathrm{~min}$ at 1 volt $\mathrm{cm}^{-1}$ at $300 \mathrm{~mA}$. Slides were stained with SYBR green and viewed under a Leica TCS SP2 UV Confocal Laser Scanning Microscope. The SYBR green was excited by the $488 \mathrm{~nm}$ argon laser and the emission detected at 496-549 nm. Analysis of comets was performed using Komet 5 software (Andor Technology, Belfast, Northern Ireland). Fifty comets were analysed for each treatment group to give values for the Olive tail moment and comet tail length.

Crosslinking was expressed as a percentage decrease in Olive tail moment using the formula below as previously described (Hartley et al, 1999).

$\%$ decrease in tail moment $=$

$$
\left\{1-\left[\frac{\left(\text { TMiS }^{4} \text { TdR-UVA }- \text { TMCont }\right)}{(\text { TMiCont }- \text { TMCont })}\right]\right\} \times 100
$$

where TM iCont $=$ tail moment of irradiated control cells; TM iS ${ }^{4}$ TDR-UVA = tail moment of irradiated cells treated with $S^{4} \mathrm{TdR}$ and UVA; TMCont $=$ tail moment of unirradiated control cells.

To discriminate DNA-DNA crosslinks from DNA-protein crosslinks, a proteinase $\mathrm{K}$ treatment was performed. After lysis, slides were washed in TE buffer (10 mM Tris, $1 \mathrm{~mm}$ EDTA, pH 10), then covered with $100 \mu \mathrm{l}$ proteinase $\mathrm{K}$ (Sigma) $\left(1 \mathrm{mg} \mathrm{ml}^{-1} \mathrm{TE}\right.$ buffer) and incubated for $2 \mathrm{~h}$ in a humidified incubator at $37^{\circ} \mathrm{C}$. Controls were incubated with $100 \mu \mathrm{l}$ TE buffer only. Following incubation, slides were processed as above.

\section{Assessment of apoptosis}

Caspase 3 and 7 activities were measured using the Caspase-Glo Assay (Promega, Southampton, UK). The MYU-3L and AY27 cells were incubated in the presence or absence of $S^{4} \mathrm{TdR}(100 \mu \mathrm{M})$ for two cell-doubling times and exposed to $10 \mathrm{~kJ} \mathrm{~m}^{-2}$ UVA. Cells were 
re-incubated for $24 \mathrm{~h}$ in fresh medium. Caspase-Glo 3/7 reagent was added and luminescence was measured.

AY27 and MYU-3L cells treated with $S^{4} \mathrm{TdR}(100 \mu \mathrm{M})$ and UVA $\left(10 \mathrm{~kJ} \mathrm{~m}^{-2}\right)$ were suspended and stained with Annexin V -FITC (Beckman Coulter, High Wycombe, UK). Samples were analysed by flow cytometry using BD FACScan II Flow cytometer (BD Biosciences, Oxford, UK).

\section{Orthotopic animal model}

All in vivo work was carried out under strict regulatory approval (LREC licence PPL 60/2836). Female Fischer rats (F344) weighing $170-200 \mathrm{~g}$ were anaesthetised using inhaled isofluorane. Rats were catheterised using a 20-gauge cannula. The bladder was preconditioned using $0.1 \mathrm{~N} \mathrm{HCl}$ to strip the epithelium and neutralised with $0.1 \mathrm{~N} \mathrm{KOH}$ followed by a PBS wash to create a surface suitable implantation of tumour cells. Suspensions of MYU-3L cells $\left(1 \times 10^{5}\right.$ in $0.4 \mathrm{ml}$ RPMI 1640 per $50 \%$ FCS $)$ were instilled for $1 \mathrm{~h}$. Rats were turned $90^{\circ}$ every $15 \mathrm{~min}$ to encourage even distribution of tumour cells. Two days after tumour cell instillation, the urothelium was completely denuded, with cancer cells overlying oedematous subepithelial connective tissue. At day 5 postinstillation, $80 \%$ of tumours showed invasion into the subepithelial connective tissue consistent with stage pT1 tumours. The subendothelial connective tissue showed increased vascularity over normal rats' bladders. Tumour depth varied between $0.2-1.4 \mathrm{~mm}$. By day $10,100 \%$ of tumours progressed to muscle invasive disease (pT2). At 21 days post-instillation, all tumours were histological stage $\mathrm{T} 3$ with invasion into the perivesical fat and areas of tumour necrosis. The progression to invasion in the MYU-3L model without early metastases makes this a suitable model of progression in high-risk NMIBC.

\section{Administration of $\mathrm{S}^{4} \mathrm{TdR}$ and UVA light}

Thiothymidine solution was dissolved in sterile water up to doses of $16 \mathrm{mg}$ in $0.4 \mathrm{ml}$ aliquots. An intravesical instillation time of $2 \mathrm{~h}$ was used. Intravenous injections of $S^{4} \mathrm{TdR}\left(160 \mathrm{mg} \mathrm{kg}^{-1}\right)$ were reconstituted in $1.0 \mathrm{ml}$ sterile water and administered via tail vein injection. Whole bladder UVA exposure was achieved using a UVCLEAN fibre optic system (Sensor Electronics, Coumbia, NC, USA). This consisted of a portable power supply coupled to a UV $(320-340 \mathrm{~nm})$ light emitting diode set to the maximum power setting $(18 \mathrm{~mA})$. The UV clear optic fibre $(0.6 \mathrm{~mm}$ diameter $)$ fitted through the urethral cannula (20 gauge) without any leak. The bladder was filled with $0.1 \mathrm{ml}$ sterile PBS to partially distend the bladder and the fibre was advanced so that the tip sat $1-2 \mathrm{~mm}$ beyond the end of the cannula. Calculations using the surface area of the fibre tip and the estimated surface area of the bladder (BSA) using the equation $\mathrm{BSA}=4.83$ (bladder volume) ) $^{2 / 3}$ in $\mathrm{cm}^{2}$ (Xiao et al, 2003) indicated that a $15 \mathrm{~min}$ exposure would be equivalent to $5 \mathrm{~kJ} \mathrm{~m}^{-2}$ UVA delivery.

\section{Measurement of thymidine and $S^{4} \mathrm{TdR}$ levels in rat serum}

Thiothymidine concentrations in $100 \mu \mathrm{l}$ samples of rat plasma were determined following acetonitrile protein extraction and comparison with a standard curve of thymidine and $\mathrm{S}^{4} \mathrm{TdR}$ in human plasma. Dried samples were re-suspended in $200 \mu$ l of mobile phase $(0.05 \mathrm{M}$ $\mathrm{NH}_{3}$-Ac pH 5.0). Samples were analysed as described above.

\section{Histopathology}

To confirm that MYU-3L cells retained their carcinoma phenotype, indirect immunoperoxidase staining of paraffin embedded bladder tumour specimens with a pan-cytokeratin cocktail (Abcam, Cambridge, UK) was performed using standard immunohistochemistry protocols. Antigen retrieval was carried out using a citrate buffer and bound antibody was detected using biotin-conjugated rabbit antimouse immunoglobulins and the streptABC kit (DAKO, Ely, Cambridgeshire, UK) and Sigmafast diaminobenzidine tablets (Sigma).

\section{RESULTS}

\section{Thiothymidine is incorporated into the DNA of bladder cancer cells in vitro}

Each of the bladder carcinoma cell lines was assessed for the ability to incorporate $\mathrm{S}^{4} \mathrm{TdR}$ into DNA. Following culture in the presence of $200 \mu \mathrm{M} \mathrm{S}{ }^{4} \mathrm{TdR}$ for two cell-doubling times, the thiobase replaced $\sim 0.63 \%$ of DNA TdR in AY27 cells. Under the same conditions, $\sim 0.50 \%$ of DNA TdR was replaced by $\mathrm{S}^{4} \mathrm{TdR}$ in MBT2 cells. The extent of substitution in MYU-3L and RT4 cells was lower, at 0.22 and $0.15 \%$, respectively (Figure 1 ). These levels of $\mathrm{S}^{4} \mathrm{TdR}$ incorporation are comparable to those reported in human fibroblasts (Massey et al, 2001). When AY27 and MYU-3L cells were cultured in a medium with $200 \mu \mathrm{m}$ thiothymidine, thiothymidine was detectable in DNA extracts after $2 \mathrm{~h}$ of incubation, replacing 0.23 and $0.05 \%$ for each cell line, respectively.

Raltitrexed increased $\mathrm{S}^{4} \mathrm{TdR}$ incorporation into DNA. Under similar conditions $\left(200 \mu \mathrm{M}\right.$, two cell doublings), the addition of $\mathrm{IC}_{5}$ and $\mathrm{IC}_{50}$ concentrations of raltitrexed increased DNA $\mathrm{S}^{4} \mathrm{TdR}$ incorporation 7- and 11-fold, respectively, in MYU-3L cells. $\mathrm{IC}_{5}$ raltitrexed concentrations increased $S^{4} \mathrm{TdR}$ incorporation 4-, 20- and 4-fold, respectively, in MBT2, RT4 and AY27 cells and these values were even higher at $\mathrm{IC}_{50}$ concentrations. These findings are summarised in Table 1.

\section{Thiothymidine sensitises bladder cancer cell lines to UVA}

When MYU-3L cells were treated with a range of $S^{4} \mathrm{TdR}$ concentrations and subsequently exposed to increasing UVA doses, there was a $\mathrm{S}^{4} \mathrm{TdR}$ - and UVA dose-dependent growth inhibitory effect (Figure 2). In control experiments, no growth inhibition was observed in cells treated with $\mathrm{S}^{4} \mathrm{TdR}$ alone up to $300 \mu \mathrm{M}$ or with UVA at doses less than $50 \mathrm{~kJ} \mathrm{~m}^{-2}$ (data not shown). After 10 and $200 \mu \mathrm{M} \mathrm{S}{ }^{4} \mathrm{TdR}$ and $1 \mathrm{~kJ} \mathrm{~m}^{-2}$ UVA, growth inhibition was 29 and $75 \%$, respectively, increasing to 89 and $98 \%$ growth inhibition at $5 \mathrm{~kJ} \mathrm{~m}^{-2}$. Consistent with their more extensive DNA substitution, a dose of $1 \mathrm{~kJ} \mathrm{~m}^{-2}$ UVA produced 90 and $100 \%$ growth inhibition in AY27 cells cultured in 10 and $200 \mu \mathrm{M} \mathrm{S}{ }^{4} \mathrm{TdR}$ (data not shown).

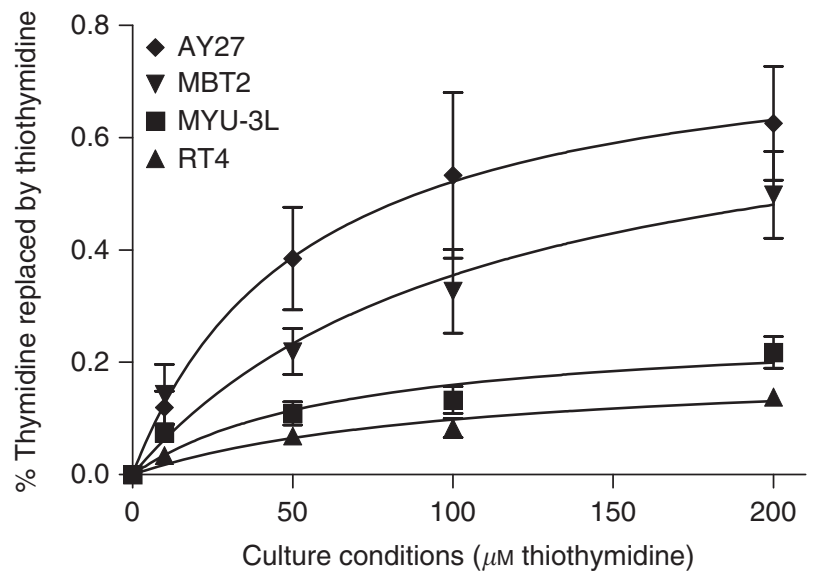

Figure I Incorporation of $S^{4} T d R$ into cellular DNA. Cell lines were incubated in concentrations of $\mathrm{S}^{4} \mathrm{TdR}$ as indicated on the $x$ axis for two cell-doubling times. Following DNA extraction and digestion, nucleosides were analysed using LC/MS/MS to determine the percentage of DNA thymidine replaced by $S^{4} T d R$ ( $y$ axis). 


\section{UVA sensitisation by $S^{4} \mathrm{TdR}$ is further augmented by raltitrexed}

The enhanced DNA $S^{4} \mathrm{TdR}$ incorporation after raltitrexed treatment was associated with increased UVA sensitivity. In the

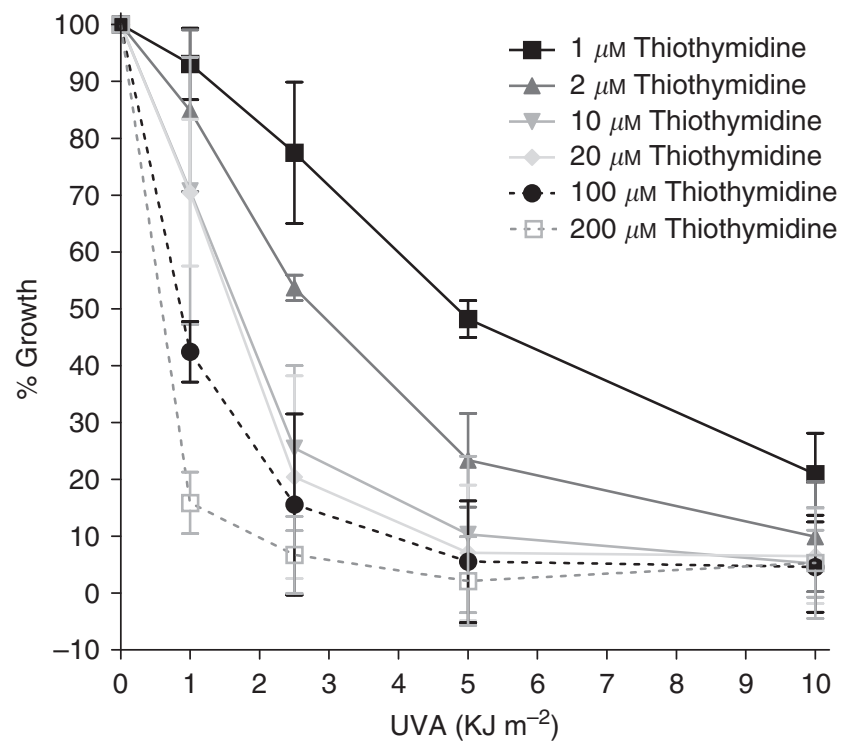

Figure 2 Sensitisation of MYU-3L bladder cancer cells to low doses of UVA. MYU-3L cells were incubated in the presence of $S^{4} T d R$ as indicated in the legend for two cell-doubling times. Cells were exposed to UVA ( $x$ axis) and re-incubated for a further $72 \mathrm{~h}$ in fresh medium. Growth was assessed using the SRB assay ( $y$ axis). absence of raltitrexed, $10 \mu \mathrm{M} \mathrm{S}{ }^{4} \mathrm{TdR}$ and $0.5 \mathrm{~kJ} \mathrm{~m}^{-2}$ UVA produced a growth inhibition of $8 \%$ in MYU-3L cells (Figure 3 ). When combined with a range of increasing raltitrexed concentrations up to $7.5 \mathrm{~nm}$, the same $\mathrm{S}^{4} \mathrm{TdR}$ concentration and UVA dose resulted in a progressively increasing growth inhibition of up to $65 \%$. Raltitrexed also increased the $\mathrm{S}^{4} \mathrm{TdR} / \mathrm{UVA}$ sensitivity of RT4, MBT2 and AY27 cells. The results for MBT2 and AY27 were comparable to those obtained for MYU-3L cells. Consistent with the more pronounced effect of raltitrexed on DNA $S^{4} \mathrm{TdR}$ in RT4, the differential sensitivity attributable to raltitrexed was greatest in these cells. (Figure 3). In control experiments, raltitrexed alone did not confer any additional sensitivity to UVA (data not shown).

\section{Thiothymidine causes DNA crosslinks and apoptosis following UVA exposure}

The DNA lesions induced by $\mathrm{S}^{4} \mathrm{TdR} / \mathrm{UVA}$ treatment were assessed using the comet assay. The crosslinking of DNA $S^{4} \mathrm{TdR}$ was measured as a reduction in comet tail moments in X-irradiated cells. Typical comet images are shown in Figure 4. An X-ray dose of $20 \mathrm{~Gy}$ induced comets in the nondrug-treated control cells (Figures $4 \mathrm{~A}$ and $\mathrm{G}$ ). The length of the comet tail was significantly shorter in X-irradiated cells that had previously been treated with $200 \mu \mathrm{M} \mathrm{S}{ }^{4} \mathrm{TdR}$ and $10 \mathrm{~kJ} \mathrm{~m}^{-2}$ UVA. The mean reduction in Olive tail moment by $\mathrm{S}^{4} \mathrm{TdR} / \mathrm{UVA}$ was 55 and $51 \%$ for MYU-3L and AY27 cells, respectively, in three independent experiments. As expected, there was no visible DNA migration in samples that were not X-irradiated. To examine whether formation of DNA-Protein crosslinks by $\mathrm{S}^{4} \mathrm{TdR} / \mathrm{UVA}$ contributed to the reduced DNA migration, slides were treated with proteinase $\mathrm{K}$ before electrophoresis. Protease digestion caused a $24 \%$ increase in tail moment compared with untreated slides (data not shown).
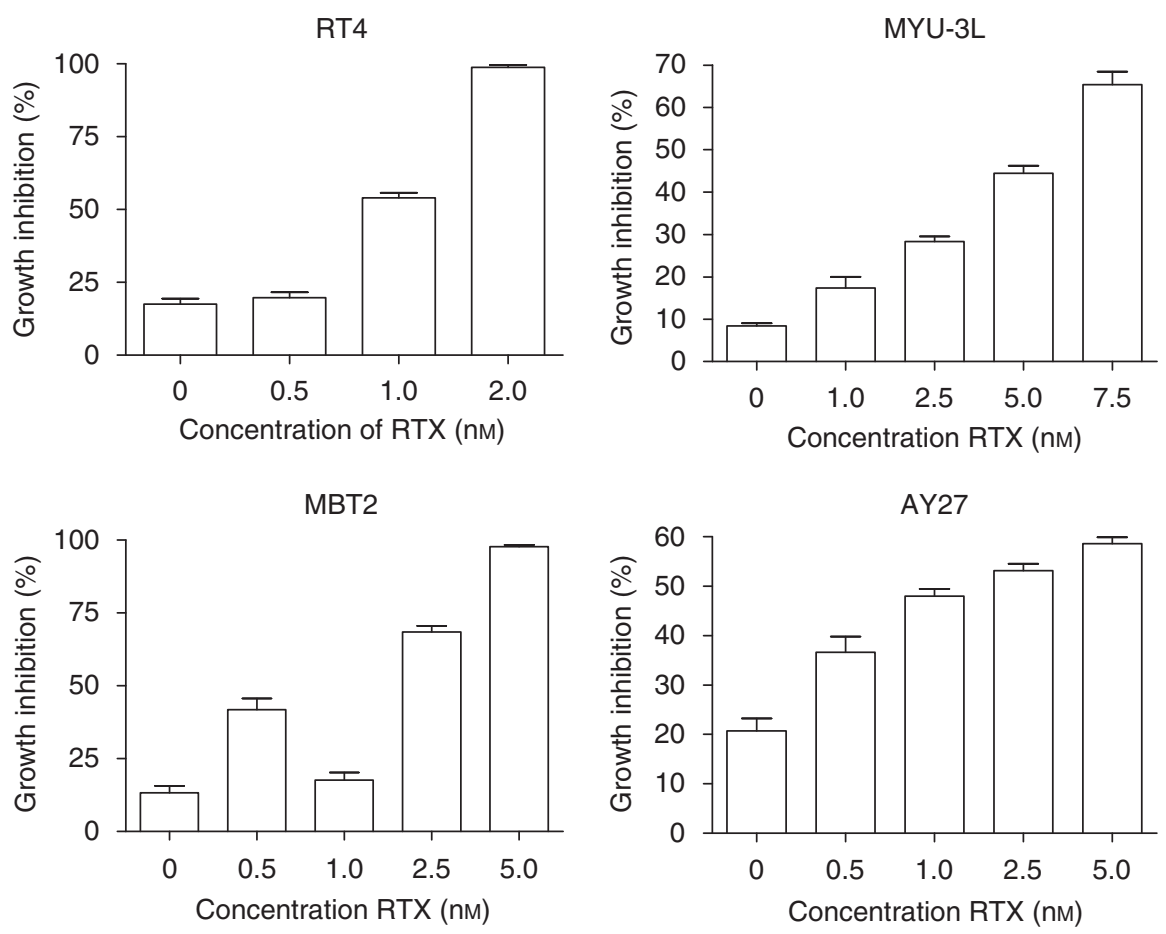

Figure 3 Augmentation of UVA sensitisation using raltitrexed. Cells were cultured for two cell-doubling times with $20 \mu \mathrm{M} \mathrm{S}^{4} \mathrm{TdR}$ and RTX as indicated. Cells were detached and re-plated in 96-well plates and irradiated under a thin layer of PBS $\left(0.5 \mathrm{~kJ} \mathrm{~m}^{-2}\right.$ UVA for MYU-3L cells and $2.5 \mathrm{~kJ} \mathrm{~m}{ }^{-2}$ for RT4, MBT2 and AY27 cells). After irradiation, I $50 \mu$ l of fresh growth medium was replaced. Surviving cells were stained and scored after 5 days. All values represent the mean \pm s.e.m. of 10 replicates. 

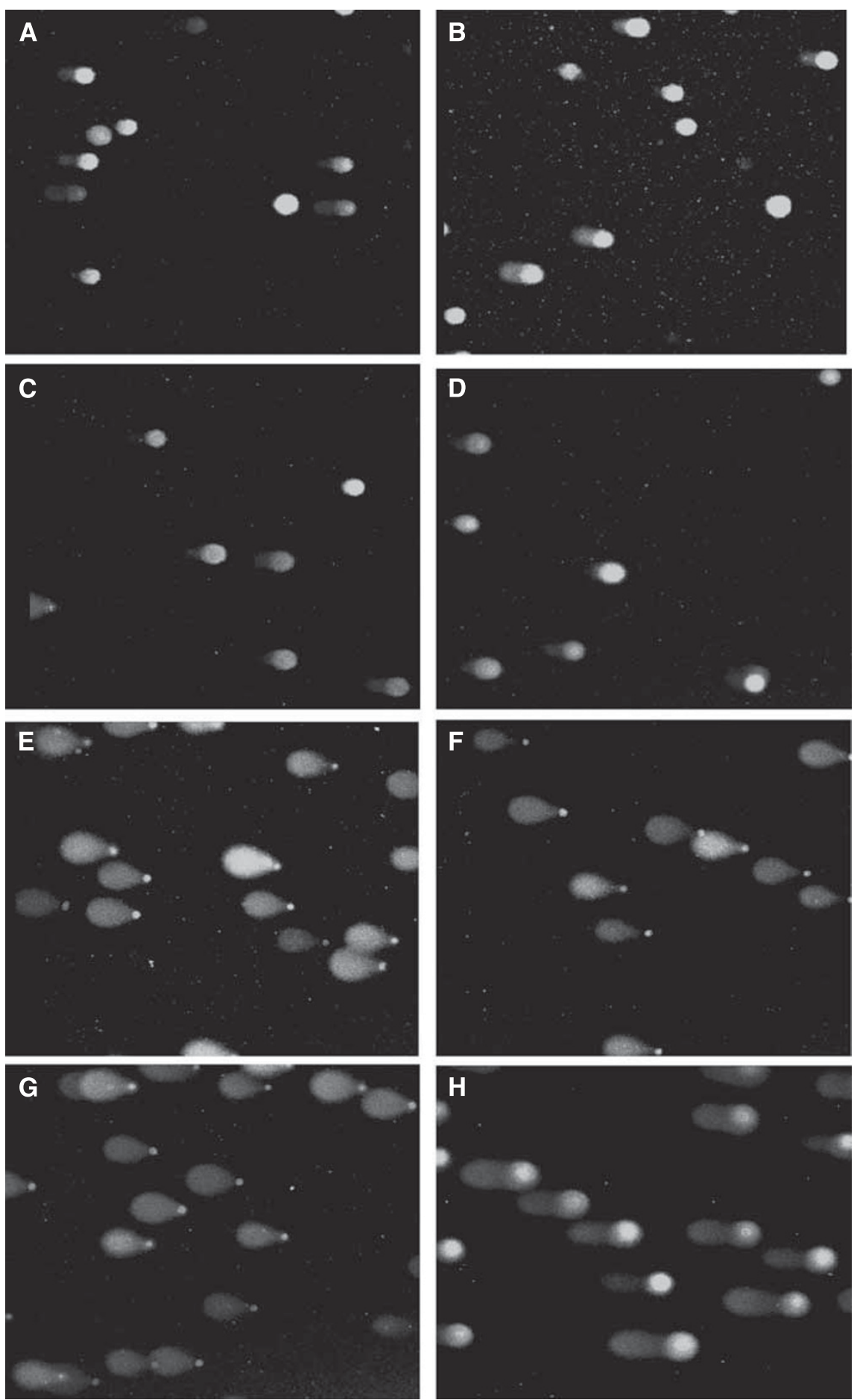

Figure 4 Typical comet images from MYU-3L cells treated with $S^{4} T d R$ and UVA. Thiothymidine treatment was for two cell-doubling times at $200 \mu \mathrm{M}$ and UVA exposure was at $10 \mathrm{k} \mathrm{m}^{-2}$. Irradiated cells were exposed to $20 \mathrm{~Gy}$ X-irradiation. (A) Unirradiated control; (B) Unirradiated $\mathrm{S}^{4} \mathrm{TdR}$ control; (C) Unirradiated UVA control; (D) Unirradiated $\mathrm{S}^{4} \mathrm{TdR}$ and UVA; (E) Irradiated $\mathrm{S}^{4} \mathrm{TdR}$ control; (F) Irradiated UVA control; (G) Irradiated control; (H) Irradiated $S^{4} T d R+$ UVA.

Thiothymidine/UVA treatment induced apoptosis in the bladder carcinoma cells

Twenty-four hours following treatment with $100 \mu \mathrm{M} \mathrm{S}{ }^{4} \mathrm{TdR}$ and $10 \mathrm{~kJ} \mathrm{~m}^{-2}$ UVA, cells appeared shrunken with condensed nuclei. By $18 \mathrm{~h}$ after irradiation, caspase 3 and 7 activity in the culture medium was increased by factors of 5.2 and 5.7 for MYU-3L cells and AY27 cells, respectively, compared with controls (Figure 5). The induction of apoptosis was confirmed by flow cytometry analysis. By $18 \mathrm{~h}$ after UV irradiation of cells pretreated with $100 \mu \mathrm{M}$ S4TdR, annexin binding was detectable in 29 and $26 \%$ of MYU-3L and AY27 cells, respectively. The corresponding figures for untreated cells were 5 and $7 \%$. 
Thiothymidine accumulates in DNA of bladder tumours following intravenous or intravesical administration

Bladder tumours were successfully established in F334 Fischer rats by instillation of MYU-3L bladder cancer cell suspensions into

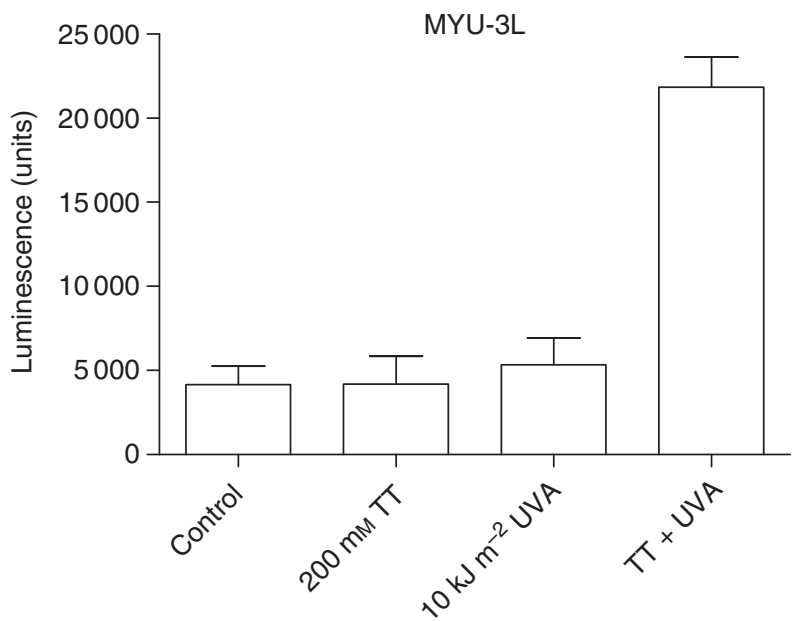

Treatment

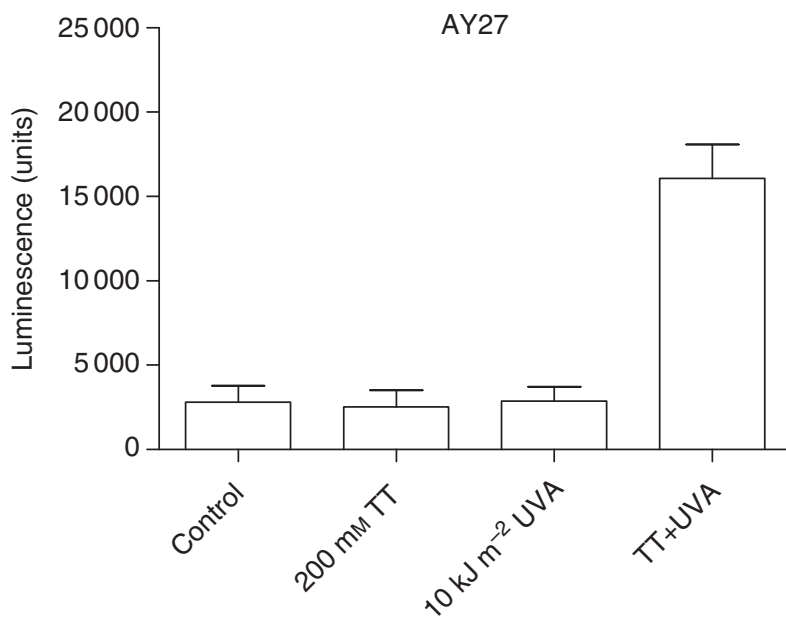

Treatment

Figure 5 Caspase 3/7 activity following treatment with $S^{4} T d R$ and UVA. MYU-3L (above) and AY27 (below) cells were cultured in white walled multi-well plates. Cells were treated with $200 \mu \mathrm{M} \mathrm{S} \mathrm{S}^{4} \mathrm{dR}, 10 \mathrm{~kJ} \mathrm{m^{-2 }}$ UVA or a combination of both; four wells were set up for each treatment group. Twenty-four hours after UVA exposure, $50 \mu \mathrm{l}$ of Caspase-Glo 3/7 reagent was added to each well and incubated for $\mathrm{I} h$ at room temperature. Luminescence was measured in a plate reading luminometer. The graphs above represent the mean \pm s.e.m. of three independent experiments each consisting of four replicates. preconditioned rats' bladders. At day 2 after tumour implantation, clumps of cells were visible in the bladder lumen with early adherence to the denuded urothelium. By day 5 post-instillation, stage pT1 bladder tumours were seen with infiltration into the subepithelial connective tissue and tumour depth of $<1 \mathrm{~mm}$. Bladders were macroscopically identical to normal rat bladders. Tumours stained positively with a pan-cytokeratin cocktail confirming a carcinoma phenotype. Tumours showed a rapid growth phase from day 6-21 with formation of bulky tumours progressing to muscle invasive and locally advanced disease, but without evidence of metastatic spread. Rat bladders examined histologically between day 5 and day 21 showed tumour development in 45 out of 50 animals inoculated with tumour cells.

Thiothymidine was detectable in bladder tumour DNA following intravenous administration at a dose of $160 \mathrm{mg} \mathrm{kg}^{-1}$ (32 $\mathrm{mg}$ for a $200 \mathrm{~g}$ rat) one week after tumour seeding (Table 2). Tissues were sampled $2 \mathrm{~h}$ and $20 \mathrm{~h}$ after injection and concurrent blood samples were taken at the time of euthanasia. Specimens of bladder, kidney, liver, skin and eye were obtained from three animals at each time point - one control and two rats in which tumour cells were implanted. Three tissue samples from each organ were analysed per animal. At two hours post-injection, $S^{4} \mathrm{TdR}$ replaced $0.0018 \pm 0.0002 \%$ of thymidine in bladder tumour DNA, but was undetectable in DNA from control bladders. By $20 \mathrm{~h}$, substitution in tumour DNA had increased nearly 10 -fold to $0.0140 \pm 0.0006 \%$ and $S^{4} \mathrm{TdR}$ was present in DNA from control bladders at $0.0055 \pm 0.0002 \%$. Thiothymidine was detectable in kidney and liver DNA and the levels of substitution increased between 2 and $20 \mathrm{~h}$ (Table 2). Incorporation into skin and eye was much lower $(<0.001 \%)$. Thiothymidine was cleared quite rapidly from blood; serum concentrations were $27.7 \pm 2.0 \mu \mathrm{M}$ at $2 \mathrm{~h}$ and $0.15 \pm 0.01 \mu \mathrm{M}$ at $20 \mathrm{~h}$.

Intravesical instillation of $\mathrm{S}^{4} \mathrm{TdR}$ was also examined. Thiothymidine $(0.0040 \pm 0.0100 \%)$ was present in DNA of bladder tumours immediately after installation for $2 \mathrm{~h}(16 \mathrm{mg}$ in $0.4 \mathrm{ml}$ sterile water) (Table 2). This was the maximum value observed and the level of substitution decreased at 4 and $20 \mathrm{~h}$ post-instillation to $0.0028 \pm 0.0010 \%$ and $0.0019 \pm 0.00003 \%$. In control bladders, $\mathrm{S}^{4} \mathrm{TdR}$ was present at $0.0010 \%$ immediately following and at $4 \mathrm{~h}$ post-instillation, but was undetectable by $20 \mathrm{~h}$. A similar pattern was observed for other organs, with a maximum $S^{4} \mathrm{TdR}$ incorporation observed immediately after drug instillation and decreasing with time (Table 2). Plasma $\mathrm{S}^{4} \mathrm{TdR}$ concentration was $0.094 \mu \mathrm{M}$ immediately after intravesical instillation and $0.052 \mu \mathrm{M} 4 \mathrm{~h}$ later. Data were not available for the $20 \mathrm{~h}$ time point.

\section{Thiothymidine and UVA have antitumour activity in an orthotopic model of bladder cancer}

The effectiveness of $\mathrm{S}^{4} \mathrm{TdR} / \mathrm{UVA}$ as an anticancer treatment was tested in the rat bladder tumour model. The experiment comprised six treatment groups: no-treatment controls, intravenous $\mathrm{S}^{4} \mathrm{TdR}$ only, intravesical $S^{4} \mathrm{TdR}$ only, UVA only, intravenous $S^{4} \mathrm{TdR}$ plus

Table $2 S^{4} T d R$ incorporation into DNA in different tissues following intravenous ( $60 \mathrm{mg} \mathrm{mk}^{-1}$ ) or intravesical ( $16 \mathrm{mg}$ in $4 \mathrm{ml}$ for $2 \mathrm{~h}$ ) administration.

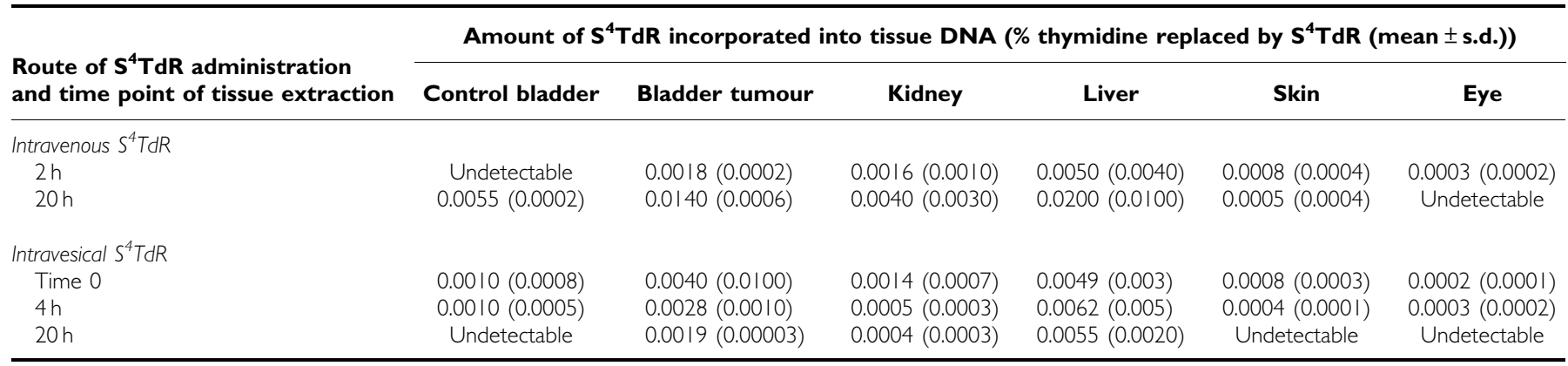




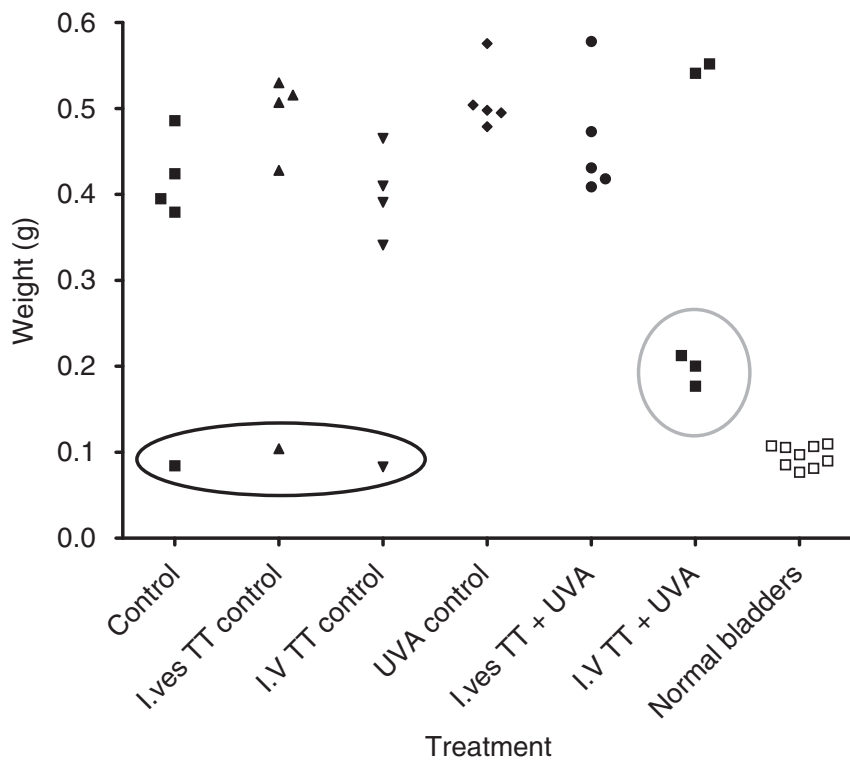

Figure 6 Assessment of tumour burden following $S^{4} T d R$ and UVA treatment in rats. Bladders were excised and weighed following thiothymidine and UVA treatment. Tumours failed to establish in three rats (circled black). Responses in the intravenous $S^{4} T d R$ and UVA group are circled in grey.

UVA and intravesical $S^{4}$ TdR plus UVA. All groups contained five rats. MYU-3L tumour cells were instilled in all rat bladders using the intravesical tumour model described above. Five days after implantation, rats in the treatment arm and rats in the $S^{4} \mathrm{TdR}$ only control group were given $S^{4} \mathrm{TdR}$ intravenously $\left(160 \mathrm{mg} \mathrm{kg}^{-1}\right)$ or intravesically $(16 \mathrm{mg}$ in $0.4 \mathrm{ml})$. After $20 \mathrm{~h}$, the treatment groups and the UVA only control group were anaesthetised and UVA $\left(5 \mathrm{~kJ} \mathrm{~m}^{-2}\right)$ delivered into the bladders via an optical fibre. The control groups were anaesthetised and the UVA probe inserted with no UVA delivery. Fifteen days after the UVA treatment (3 weeks post-tumour implantation), rats were killed. Bladders were removed, weighed to assess tumour bulk, and formalin-fixed for histopathological analysis and tumour staging.

All rats survived in good condition until the end of the study, except for one animal from the UVA only group that displayed significant weight loss and signs of stress. It was killed on day 19 and found to have bilateral pyelonephritis with renal microabscesses and patchy renal infarction. Histological examination revealed a large locally advanced stage pT3 bladder tumour.

Tumours failed to take in three rats; one each from the notreatment control arm, the intravesical $S^{4} \mathrm{TdR}$ only arm and the intravenous $\mathrm{S}^{4} \mathrm{TdR}$ only arm (Figure 6). The bladders from these animals were similar to normal bladders in weight and appeared histologically normal with no evidence of tumour or inflammation. With the exception of the group that received intravenous $\mathrm{S}^{4} \mathrm{TdR}$ and UVA, all other animals developed advanced tumours. Each bladder weighed $>0.3 \mathrm{~g}$ and histological examination confirmed the presence of advanced carcinoma.

Post-treatment bladder changes were observed in three of the five animals that received intravenous $\mathrm{S}^{4} \mathrm{TdR}$ and UVA (Figure 6). Macroscopic evaluation of the bladders from the three responders revealed some enlargement compared with normal bladders, but significantly less than that of tumour-bearing bladders. Histological examination revealed no evidence of tumour cells. However, there was epithelial proliferation and inflammation with lymphocytes, histiocytes, lymphocytes and eosinophils in addition to haemosiderin deposition. There was no evidence of fibrosis. These findings suggested a proliferative reparatory response with reactive urothelial hyperplasia at the site of inflammation. Importantly, each of the bladders from the responding animals were distinctly different from those in which the tumour failed to implant and from normal bladders that did not show any evidence of inflammation. The bladders of the other two animals in this treatment arm, which were not considered to be treatment responses, contained locally advanced tumours that were macroscopically and histologically identical to the tumours observed in the control groups.

In the group treated with intravesical $\mathrm{S}^{4} \mathrm{TdR}$ and UVA there was no evidence of response to the treatment. There were no observable differences in the macroscopic appearances of the bladders compared with the untreated tumour control groups and microscopic evaluation revealed locally advanced tumours.

\section{DISCUSSION}

Evidence for the potential use of $S^{4} \mathrm{TdR}$ as a UVA photosensitising agent comes from in vitro work with cultured human cells (Massey et al, 2001; Reelfs et al, 2007). Those initial studies indicated that $\mathrm{S}^{4} \mathrm{TdR}$ is a nontoxic thymidine analog that is incorporated to significant levels into DNA.

Measurements of LC/MS showed that $\mathrm{S}^{4} \mathrm{TdR}$ is incorporated into the DNA of bladder carcinoma cells in vitro and can replace up to almost $1 \%$ of DNA thymidine without significantly affecting cell growth. Even though all measurements were made after two cell doublings, the extent of $S^{4} \mathrm{TdR}$ DNA substitution was related to the rate of cell division of each of the cell lines. The AY27 cells had the shortest cell-doubling time and $\mathrm{S}^{4} \mathrm{TdR}$ incorporation in these cells was the greatest. Conversely, RT4 cells grew more slowly and had the lowest rate of $S^{4} \mathrm{TdR}$ incorporation. These results support the idea that in cells with faster replication, thymidine salvage is important to sustain DNA turnover. Therefore, tumours will incorporate more $\mathrm{S}^{4} \mathrm{TdR}$ than healthy urothelium, as confirmed by the greater incorporation in bladder tumours compared with normal bladder in the orthotopic model.

The presence of $S^{4} \mathrm{TdR}$ in DNA sensitised each of the cell lines to subsequent UVA exposure. The growth inhibitory effect was dose dependent for both UVA dose and $S^{4} \mathrm{TdR}$ concentration. Even very low, nontoxic, doses of both $\mathrm{S}^{4} \mathrm{TdR}(10 \mu \mathrm{M})$ and UVA $\left(5 \mathrm{~kJ} \mathrm{~m}^{-2}\right)$ combined to produce a significant growth inhibition.

The TS inhibitor, raltitrexed, augmented DNA S ${ }^{4} \mathrm{TdR}$ incorporation in all cell lines and acted as a dose modifier for UVA sensitivity. Pretreatment with $\mathrm{IC}_{5}$ concentrations of raltitrexed increased $S^{4} \mathrm{TdR}$ incorporation by factors of between 4 and 20 . The effect of raltitrexed was particularly marked in the cells (RT4 and MYU-3L) in which $S^{4} \mathrm{TdR}$ incorporation was lowest. These two cell lines had the slowest growth rates and this observation is consistent with the dependence of $\mathrm{S}^{4} \mathrm{TdR}$ incorporation on active thymidine salvage mediated by TK, which is upregulated in rapidly growing cells. A reduced reliance on TS-mediated de novo pyrimidine nucleotide synthesis in the rapidly growing MBT2 and AY27 cells results in a less dramatic effect of raltitrexedmediated TS inhibition on $\mathrm{S}^{4} \mathrm{TdR}$ incorporation. In all cases, the increased incorporation of $\mathrm{S}^{4} \mathrm{TdR}$ was associated with a heightened sensitivity to UVA.

Treatment with $\mathrm{S}^{4} \mathrm{TdR} / \mathrm{UVA}$ induces DNA adducts that significantly retard DNA migration in the Comet assay. This effect was partially reversed by proteinase $\mathrm{K}$ digestion, indicating that $\mathrm{S}^{4} \mathrm{TdR} / \mathrm{UVA}$ causes the formation of DNA-protein crosslinks. These are likely to be difficult lesions for the DNA repair machinery to deal with and they may be a significant contributor to the cell death by apoptosis that was observed as a consequence of $\mathrm{S}^{4} \mathrm{TdR} / \mathrm{UVA}$ treatment.

Thiothymidine had no overt toxic effects in rats following either intravesical or intravenous administration of $S^{4} \mathrm{TdR}$. Furthermore, there was no significant incorporation of $S^{4} \mathrm{TdR}$ into DNA of skin 
and eye, the two tissues most susceptible to photosensitisation. Significant incorporation was noted in liver and kidney, tissues that are not normally exposed to UVA. Significant incorporation into the DNA of bladder tumours was observed following intravenous or intravesical administration of $\mathrm{S}^{4} \mathrm{TdR}$. The levels of circulating thymidine are particularly high in rats $(5-8 \mu \mathrm{M})$ compared to humans $(0.05 \mu \mathrm{M})$ and to that in standard culture medium $(0.02 \mu \mathrm{M})$. As $\mathrm{S}^{4} \mathrm{TdR}$ has to compete for cellular uptake against this high background level of thymidine, this suggests that $S^{4} \mathrm{TdR} / \mathrm{UVA}$ may be even more effective in humans. Intravenous administration produced a significant level of $S^{4} \mathrm{TdR}$ incorporation into bladder tumour DNA. The DNA $S^{4} \mathrm{TdR}$ level at $2 \mathrm{~h}$ was somewhat higher following intravesical administration, however, the experimental protocol required that UVA irradiation was performed $20 \mathrm{~h}$ after $\mathrm{S}^{4} \mathrm{TdR}$ was administered.

No antitumour response was seen following treatment with intravesical S${ }^{4} \mathrm{TdR}(16 \mathrm{mg})$ and $\operatorname{UVA}\left(5 \mathrm{~kJ} \mathrm{~m}^{-2}\right)$. The time interval between $\mathrm{S}^{4} \mathrm{TdR}$ administration and UVA delivery is the factor most likely to account for this failure to respond. Based on our DNA $S^{4} \mathrm{TdR}$ measurements, the optimum time for UVA delivery would have been immediately following $S^{4} \mathrm{TdR}$ instillation. The constraints of the in vivo project licence precluded this treatment option, however.

Three out of the five rats treated with intravenous $S^{4} T d R$ and UVA had visible and histological bladder appearances which were markedly different from control rats bladder. Microscopic examination indicated a proliferative repair process with no evidence of tumour cells. This was in contrast to the rats in which tumours failed to take and in which the bladders exhibited normal histology. These histological differences are consistent with an inflammatory process representing repair in the treated animals, and suggesting that their tumours regressed following $\mathrm{S}^{4} \mathrm{TdR}$ and UVA treatment. The timing of UVA administration following intravenous $S^{4} \mathrm{TdR}$ appeared to be more favourable than for intravesical administration and DNA $S^{4} \mathrm{TdR}$ was maximal at this time. As $\mathrm{S}^{4} \mathrm{TdR}$ incorporation into DNA in this in vivo model was less than that seen to be optimal in in vitro experiments, some other mechanism of antitumour effect may be operating. Further investigations would be needed to determine other potential effects of $\mathrm{S}^{4} \mathrm{TdR} / \mathrm{UVA}$, perhaps on tumour vascularisation.

Following the in vivo treatments, an active inflammatory process was observed with no evidence of fibrosis. However, fibrosis can be a late complication following intravesical BCG and radiotherapy treatment in humans, which can be functionally disabling. Fibrosis could also be a potential adverse effect of local photodynamic treatment. Urodynamic assessment of rats bladder compliance following photodynamic treatment with 5-aminolavulenic acid (5-ALA) and red light $(630 \mathrm{~nm})$ did not previously show any functional changes post-treatment (Xiao et al, 2003). There have been reports of severe fibrosis requiring cystectomy in small series of 5-ALA treatment in humans (Walther, 2000).

Thiothymidine is a potent UVA photosensitiser in vitro. The in vivo work presented here provides the first indication that $\mathrm{S}^{4} \mathrm{TdR}$ is nontoxic in animals and may have potential as an anticancer treatment. It may offer an alternative to existing therapies for hyperproliferative diseases such as cancer, where a photodynamic approach is possible. This study offers a proof of principle that $\mathrm{S}^{4} \mathrm{TdR} / \mathrm{UVA}$ can be effective in vivo. Further work will be aimed at confirming these promising findings and optimising the timing, dose and route of $S^{4} \mathrm{TdR}$ administration in an in vivo setting as a step towards designing a clinical feasibility study.

\section{REFERENCES}

Babjuk M, Oosterlinck W, Sylvester R, Kaasinen E, Böhle A, Palou-Redorta J, European Association of Urology (EAU) (2008) EAU guidelines on nonmuscle-invasive urothelial carcinoma of the bladder. Eur Urol 54(2): $303-314$

CRUK Cancer Statistics (2010) http://info.cancerresearchuk.org/cancerstats/ incidence

Hartley JM, Spanswick VJ, Gander M, Giacomini G, Whelan J, Souhami RL, Hartley JA (1999) Measurement of DNA cross-linking in patients on ifosfamide therapy using the single cell gel electrophoresis (comet) assay. Clin Cancer Res 5(3): 507-512

Jackson RC, Jackman AL, Calvert AH (1983) Biochemical effects of a quinazoline inhibitor of thymidylate synthetase, $\mathrm{N}-(4-(\mathrm{N}-((2$-amino-4hydroxy-6-quinazolinyl)methyl)prop-2-ynylamino) benzoyl)-L-glutamic acid (CB3717), on human lymphoblastoid cells. Biochem Pharmacol 32(24): $3783-3790$

Kameyama S, Kawamata H, Kawai K, Oyasu R (1993) A new in vivo model for studying invasion and metastasis of rat and human bladder carcinomas. Carcinogenesis 14(8): 1531-1535

Kawamata H, Kameyama S, Nan L, Kawai K, Oyasu R (1993) Effect of epidermal growth factor and transforming growth factor beta 1 on growth and invasive potentials of newly established rat bladder carcinoma cell lines. Int J Cancer 55(6): 968-973

Knowles MA (2008) Molecular pathogenesis of bladder cancer. Int J Clin Onc 13(4): $287-297$

Liu J, Taylor JS (1998) Template-directed photoligation of oligodeoxyribonucleotides via 4-thiothymidine. Nucleic Acids Res 26(13): 3300 - 3304

Massey A, Xu YZ, Karran P (2001) Photoactivation of DNA thiobases as a potential novel therapeutic option. Curr Biol 11(14): 1142-1146

Mitrovski B, Pressacco J, Mandelbaum S, Erlichman C (1994) Biochemical effects of folate-based inhibitors of thymidylate synthase in MGH-U1 cells. Cancer Chemother Pharmacol 35(2): 109-114

Nikiforov TT, Connolly BA (1992) Oligodeoxynucleotides containing 4-thiothymidine and 6-thiodeoxyguanosine as affinity labels for the Eco RV restriction endonuclease and modification methylase. Nucleic Acids Res 20(6): 1209-1214
Parker SL, Tong T, Bolden S, Wingo PA (1996) Cancer statistics, 1996. CA Cancer J Clin 46(1): 5-27

Pressacco J, Mitrovski B, Erlichman C, Hedley DW (1995) Effects of thymidylate synthase inhibition on thymidine kinase activity and nucleoside transporter expression. Cancer Res 55(7): 1505-1508

Reelfs O, Xu YZ, Massey A, Karran P, Storey A (2007) Thiothymidine plus low-dose UVA kills hyperproliferative human skin cells independently of their human papilloma virus status. Mol Cancer Ther 6(9): 2487-2495

Rigby CC, Franks LM (1970) A human tissue culture cell line from a transitional cell tumour of the urinary bladder: growth, chromosone pattern and ultrastructure. Br J Cancer 24(4): 746-754

Shariat SF, Karakiewicz PI, Palapattu GS, Lotan Y, Rogers CG, Amiel GE, Vazina A, Gupta A, Bastian PJ, Sagalowsky AI, Schoenberg MP, Lerner SP (2003) Outcomes of radical cystectomy for transitional cell carcinoma of the bladder: a contemporary series from the bladder cancer research forum. J Urol 176(6): 2414-2422

Skehan P, Storeng R, Scudiero D, Monks A, McMahon J, Vistica D, Warren JT, Bokesch H, Kenney S, Boyd MR (1990) New colorimetric cytotoxicity assay for anticancer-drug screening. J Natl Cancer Inst 82(13): $1107-1112$

Soloway MS, deKernion JB, Rose D, Persky L (1973) Effect of chemotherapeutic agents on bladder cancer: a new animal model. Surg Forum 24: $542-544$

Sylvester RJ, van der Meijden AP, Lamm DL (2002) Intravesical bacillus Calmette-Guerin reduces the risk of progression in patients with superficial bladder cancer: a meta-analysis of the published results of randomized clinical trials. J Urol 168(5): 1964-1970

Walther MM (2000) The role of photodynamic therapy in the treatment of recurrent superficial bladder cancer. Urol Clin North Am 27(1): $163-170$

Warren MA, Murray JB, Connolly BA (1998) Synthesis and characterisation of oligodeoxynucleotides containing thio analogues of (6-4) pyrimidinepyrimidinone photo-dimers. J Mol Biol 279(1): 89- 100

Xiao Z, Brown K, Tulip J, Moore RB (2003) Whole bladder photodynamic therapy for orthotopic superficial bladder cancer in rats: a study of intravenous and intravesical administration of photosensitizers. J Urol 169(1): 352 -356 